\title{
2004 Malaysian General Elections Winning Formula
}

\author{
Sivamurugan Pandian \\ School of Social Sciences, Universiti Sains Malaysia \\ 10800 USM, Penang, Malaysia \\ E-mail: psiva@usm.my
}

\begin{abstract}
This paper explores Malaysia's political culture emphasizing the political consensus achieved among various ethnic groups whose lifestyle, values and beliefs differ from one another. Given the Malaysian political culture which is very much fragmented, the forming of the Alliance, or National Front (NF), has not only helped reduce ethnic-based conflicts but also manage a government. Within 4 months of taking over the reins from Tun Dr.Mahathir Mohamad, Abdullah Ahmad Badawi has led the country into its 11th general election only to obtain a landslide victory and thus, a bigger mandate as Prime Minister. This provided him the legitimacy of forming a new cabinet along with members whose sole duty is to deliver the goods to a nation of 23.2 million people. What is Abdullah Ahmad Badawi's winning formula? This paper discusses the factors which have led to the NF's overwhelming victory against a setback of Malaysia's frayed political culture augmented by its various ethnic groups and societal values. Why has this multi-ethnic and multi-cultural society picked the NF above other political parties? A special focus is given to the sparkling performance of the NF in the recently concluded elections, which saw the defeat of Alternative Front (AF). Having made inroads into the country during the 1999 elections by posing an ideological confrontation, AF effort to end the coalition's hegemony failed given its poor performance in the last elections. The party failed badly to achieve a consistent change in the society's acceptance of AF. Using the winning formula as a basis of its study, this paper will give an insight into how the NF can maintain its role as a credible government administrator since its inception in the first 1959 post-independence elections.
\end{abstract}

Keywords: General Elections, Malaysian Politics, Electoral Behaviour, Voting Trends

\section{Introduction}

A surprised and unexpected victory. These are the words that best describe the 2004 Malaysian general elections. Even though the victories of National Front (NF) were indeed expected, but the extraordinary victory, in particular NF's performance in the East Coast states indicates the new direction in the country's political system. During the campaigning period, from the date of nomination of the candidates on March 21, 2004 and prior to that, everyone was indeed afraid of placing high hopes on NF's performance especially in the states of Terengganu, Kelantan, Kedah and Perlis whereas in other states, NF was expected to form a state government easily. Analysts and political observers following the election in these states have a different view and deemed it difficult to threaten the Pan-Malaysian Islamic Party (PAS) position in Terengganu and Kelantan. In fact it was foreseen that PAS will put up a strong fight in Kedah and Perlis. Changes have again occurred in the political culture, contrary to voting attitude and patterns as seen in 1999.

\section{Election Results}

NF for the first time successfully controlled almost $90 \%$ of the Parliamentary seats or 199 seats which is more than the two thirds majority (110 seats for simple majority and 146 for two thirds majority) needed to form a government and controlled all states with a big majority except Kelantan. However, NF showed an outstanding achievement in this state by winning 21 seats from 45 seats contested.

If the 1999 election results were taken into consideration, NF's victory is outstanding. Not a single cabinet member lost and also not one won with a slim majority. They won well. Terengganu was regained overwhelmingly with a large majority (NF-28, [PAS]-4) despite NF having only 4 representatives in the State Legislative Assembly (SLA) in the past election. In Kelantan, the 1999 election saw 2 NF representatives in comparison to 43 Opposition representatives at SLA level. Today, NF has 21 members at the SLA of the respective state. United Malays National Organization (UMNO) should be given due respect as during the period after 1999 until the general elections were held, they were in a hostile environment, and seemed to always be in a state of dissatisfaction in the eyes of the people. UMNO lost 16 seats of the 88 seats contested in the 1999 election. The assumption by various parties failed when they won 109 seats of the 117 Parliamentary seats contested. At the state level, NF seized 452 seats out of 505 contested. (Note 1)

\section{Malaysia's Political Culture}

Political culture is part of the various cultures existing in a particular community. Some see it as an attitude and the comprehensive view of an individual. For Almond and Verba, culture is a psychological orientation on a social object whereas political culture is an orientation on a political object (Almond, 1972). 
According to the International Encyclopedia of Social Sciences, Political Culture is a:

"Set of attitudes, beliefs and sentiments which give order and meaning to a political process and which provide the underlying assumptions and rules that govern behaviour in the political system. It encompasses both the political ideals and the operating norms of a polity. Political culture is thus the manifestation in aggregate form of the psychological and subjective dimensions of politics" (Sills, 1979)

What is apparent is that political culture is used to portray internal factors or also known as 'soft factors' in politics such as belief, attitude and sentiments which portray a particular society. It should involve the collective action which is also emotional in nature or intellectually based and which differentiates it from other societies. According to Elazar, political culture is a combination of both, the individualistic and traditional elements. Traditional aspects refer to leadership history in a particular country, voting patterns and economic and social standing of the said country whereas individualistic elements are private business support and the initiative of an individual.

In a country like Malaysia which consists of various ethnic groups, its political culture is fragmented (Pye, 1985). It is difficult to ensure that the interests of a particular community are safeguarded while the rest are neglected. Some are even of the opinion that with the incident of the dismissal of Anwar Ibrahim, former Deputy Prime Minister, changes will occur in terms of accepting the opposition and non-governmental organization whereas upon looking at the question of the Malaysian political culture, two cultures seemed to dominate namely, the Malay and Chinese political cultures. This is due to the difference in living status, norms and practices; hence it is difficult to form assimilation between both parties. According to Almond:

“..... that the relation between political structure and culture is interactive, that one cannot explain cultural propensities without reference to historical experience and contemporary structural constraints and opportunities, and that, in turn, a prior set of attitudinal patterns will tend to persist in some form or degree and for a significant period of time, despite efforts to transform it" (Almond, 1983)

The political cultures in Malaysia are not perceived as being static but have undergone shifts in spectrum. During the colonial days, the Malaysian political culture may be deemed as being universalistic in nature, particularly with the presence of the British who gave priority to locals who want to work for them. Western Democracy was seen as a tool of the British which enabled several practices such as the Westminster model which was used for the election and the formation of a government. However, it did not last long due to the racial riot incident on May 13, 1969 which raised new challenges on the system that was being practiced. Post May 13, 1969 saw a new spectrum in the country's political arena. It brought amendments to the economic policies and the country's movement even though its basic structure remained. Political demography became important in the process of the distribution of votes and support for parties. Participation in politics and championing support for parties and public support increased. This shift in political culture in Malaysia is the main essence of this article. In 1998, changes in the political culture and spectrum occurred again, after the sacking of Anwar Ibrahim. This incident brought new directions to the course of the country's politics. Its effects were immense, particularly on the support for UMNO. Results of the 1999 elections showed new expansion in voters' voting patterns.

This new shift in the 1999 election did not occur again in the 2004 elections. Many thought that the 1999 election, the $10^{\text {th }}$ election in the history of Malaysia was to be the most challenging during the leadership of the former Prime Minister, Tun Dr. Mahathir Mohamad. This was due to the internal and external challenges to his leadership. The economic crisis of 1997 and the dismissal of Anwar played a very important role as these issues were used by the opposition to form a coalition known as, Alternative Front (AF), the best during their involvement in the election in Malaysia. Externally, the West, in particular America, Canada and Australia and several Asian leaders such as the former Indonesian President, Habibie and the President of the Philippines, Estrada to Al Gore, the former deputy President of America who caused a controversy in his speech calling for reformation during the APEC meeting, all of which was deemed to have caused the NF and UMNO to be in an hostile environment.

However, NF retained its leadership in the Federal Government with the two thirds majority as stated above. Many were of the opinion that the 'gerrymandering' factor, manipulates the general election rules and 680,000 voters who were unable to vote due to technical factors had enabled BN to win the 1999 general elections. Several other factors such as the visit of the former Prime Minister of China, Zhu Rongji from 22 to 26 November 1999 which coincided with the general election campaign period from 21 to 28 November 1999 which was considered as an endorsement of the Chinese Leadership, on the leadership of Dr Mahathir, tolerance towards Chinese medium schools and the media agenda which stated that the Non-Malays would lose their rights if PAS were to rule and establish an Islamic nation had affected the credibility of the opposition. This seemed to be the political culture practiced in this nation which is in line with the question pertaining to ethnicity. The performance by AF did increase suddenly to the extent that they were confident of gaining power in several states in the 2004 general elections. This confidence dominated their strategy but this expectation saw a decline if reference is made to the achievement of the opposition in the said general election. 
Why did this happen and what were the factors contributing to the victory of NF? This will be the focus of this article which sees the winning formula for NF as a part of the political culture in Malaysia.

\section{National Front's Winning Formula}

Malaysia's complex politics had apparently produced specific ideas and culture but pluralism remains in the country's mainstream. Many scholars held on to this principle including RK Vasil (1980), Alvin Rabushka (1973), Ismail Kassim (1979), Diane Mauzy (1983), Gordon Means (1991), and RS Milne (1978). In the establishment of the ruling party in Malaysia, the system may be divided into two, namely the birth of the Alliance (Perikatan) in 1955 until 1969 while NF dominated from 1972 to present. This is due to the independence requirements set out by the British that there should be co-operation between the various races in Malaysia and the Alliance formula deemed as the best in fulfilling the said pre-condition especially when the Municipal Council 1955 election was won by Alliance thereby allowing them to form Government.

This became a tradition and NF continues to win all elections held in Malaysia. For the purposes of this article, attention is given to the pulling factors that enabled NF to win the 2004 general election with a larger mandate which is indeed important for the future of the nation.

The most important and dominant factor that brought about NF's success is the Abdullah Badawi wave which is most conducive and fulfills the requirements of the people (Sivamurugan, 2004). The 'feel good' syndrome helped to increase Abdullah's popularity in the entire nation. When he states that a Member of Parliament should be those who are ready to serve, this statement increased the people's confidence in his leadership and felt that his agenda will be fulfilled. In line with the manifesto 'Cemerlang, Gemilang dan Terbilang' (Glorious, Excellent, Distinct), he is seen to be able to steer Malaysia toward prosperity. Under the Badawirism era, he focused on rooting out corruption, attaining a quality civil service, Islam Hadhari concept, agriculture as the vehicles toward a new economic drive, multilateral foreign relations and harmonious communal relations. These are the gist of his Malaysian agenda, the agenda to create an excellent society in a first-class nation (Sivamurugan, 2004). Badawirism gave importance to transparency, honesty and accountability to develop a glorious, excellent and distinct nation. This directly draws the attention of the majority of the voters who are between the age ranges 30 to 40 years old. This group wants a hardworking, trustworthy and responsible leader to bring the nation to greater heights not rhetorically but actually translated into performance. The elected representative performance index introduced by Abdullah also draws the interest of those in this group who are of the opinion that they have the right to their representative in the government. The people are confident of Abdullah and entrusts him to fully realize his ideals.

This is different with the opposition who did not choose a leader suitable to head the AF, what is more they selected a controversial leader that made it fragile. The demise of the late Fadzil Noor who successfully brought the opposition parties under the AF banner with a collective action also caused a bad performance by AF in the general election. In Kelantan, the Chief Minister who is the longest serving Chief Minister in the state's history, has been in service since 1990 and who had only reshuffled the exco members thrice, is seen as having administered for too long with no changes. The Chief Minister's capacity as Spiritual Leader (Tok Guru) is not at all questioned. Failure to maintain their performance in the 1999 election was deemed as "protest votes" of the people who are aware that the extreme politics of PAS did not bring progress to the country and frustrated the development of its people.

With no important and major issues as in the 1999 election which was dominated by the Anwar sacking issue, NF focused on issues such as clarifying, exhibiting and spreading Abdullah's leadership qualities of wanting to gear the nation to greater heights through his manifesto. Citizens are looked upon as assets whose interests are recognized and will be given due attention by the government. These values have drawn the attention of the public who are impressed with his ability to continue with the achievements of the nation and to bring Malaysia to greater heights (Noordin, 2004). This is contrary to the opposition who are still using their old ways which are no longer suitable with the current situation of the nation. They emphasized the same historic issues and these days voters are more rational and cannot be swayed easily. These include the action taken by the President of PAS, Datuk Seri Abdul Hadi Awang who made several controversial statements that were degrading and slanderous in nature, questioning the leadership credibility of Abdullah which were deemed by the people as an action under pressure to win the sympathy and support of voters. Abdullah's sincerity and nature was tested but he decided not to react to it. This is his strength which is most liked by the people.

The 1999 election brought the Anwar issue to light and was tainted with emotions, which PAS manipulated this issue for its own interest. Today's voters want changes that are appropriate to the turn of the century. It is especially so, when this party that fights for religious rights is not clean at all. The state government under the leadership of Hadi was also alleged to have misappropriated zakat funds and timber concessions (Massa, 2004). This caused them to be unable to face the blue wave campaign in Terengganu in year 2002 and their failure to defend the effectiveness of this campaign had trapped them and brought their failure in not winning any Parliamentary seats but only won 4 SLA seats. It is apparent that PAS is not strong on its own but the internal problems of UMNO had contributed in allowing them to 
compete with UMNO all this while. They also shared KeADILan's popularity of the 1999 election victory. The fact is PAS is unable to stand on its own and is seemed to have lost its direction when KeADILan failed. Abdullah's ability to ensure UMNO's internal problems were overcome immediately had enabled him to win a large number of votes in this election and which saw the fall of PAS heavy weights and may bring about the end of KeADILan who only won one Parliamentary seat through Datin Wan Azizah Wan Ismail at Permatang Pauh. DAP who lost heavily in the 1999 election won more seats this time. This is because they are no longer bound to the AF and had contested on their own which had enabled Lim Kit Siang and Karpal Singh to surface again in Parliament. This does not mean that this party is strong as depending on the popularity of these two names, DAP will not go any further.

Further, the rules of the Election Commission (EC) which did not allow for voter appeal had assisted the course of the election without the existence of a group that is able to vary the standing of voters at the very last stage. So were the various stringent rules by EC to ensure the non-occurrence of any untoward events again. Their strict rules have curbed excessive campaigns by contesting political parties and this has been fruitful. However, many disturbances occurred which included the voters list and more so, the changes in voting stations and printing errors until the general election in Sungai Lembing Constituency was postponed to March 28, 2004. This should be a lesson to the EC so that their ability is not questioned in future. However, the high percentage of voters, $80 \%$ in several states, showed that awareness has surfaced among the people that they have the power to ensure the leadership of today and the future.

Almost $40 \%$ of the candidates contesting under the NF party are new faces seen as being able to work together with the Prime Minister for the betterment of this country. These include people of various statuses and of varied backgrounds. This proves that NF is not lacking in new generation leaders who are able to join forces in ensuring that the nation continues to develop and be stable among the third world nations. In comparison to the scenario of the 1999 general election, the candidates that were selected and those dropped clearly shows maturity in conduct. There was evidence of sabotage in several places when the candidates of their choice were not selected. They threatened to stop the general election vehicle but as a result of the give-and-take attitude with all parties, this internal problem was solved although not fully. Candidates from other constituencies were placed in specific constituencies to avoid people of two different factions from disputing among themselves and being unpleasant with each other and this strategy has been successful. The acceptance of such candidates is better in comparison to the candidates chosen from $\mathrm{X}$ faction and seen disappointing by the $\mathrm{Y}$ faction. Strategic candidates were deemed to be among the factors contributing the NF's victory this time (Sivamurugan, 2004). The threat of the 1999 election failed in the election this time as they took the risk of placing a huge mandate in the hands of the Prime Minister including candidates who have at one time been put aside during the 1999 general election, have now made a come back to stand for election, this is seen as consequential strength to candidates from a varied background such as religious scholars, corporate figures, academicians and experienced leaders.

Economic factors also helped in NF's victory. These include the performance of the index composite which was above 900 points, among the highest and which reflects the economic standing of the nation. Second, non-Malay voters made the economy as their yardstick to decide on which party is to be chosen that will be able to ensure rapid growth. As under NF, the nation had continued to prosper and no serious economic crisis occurred during the transition of leadership, hence the community found the NF is the only party that will be able to ensure their living qualities will be better in the future. This is also the group of people who enjoyed the success of the New Economic Policy (NEP), the sharing of wealth of the country and also given the opportunity to develop the nation (Massa, 2004). As for the rural societies, they have given their trust to NF as it is the Prime Minister's own plan to use agriculture as the country's economic resources under his industrialization policies. This will directly upgrade the ability of those involved in the small and medium industry sector in the rural areas. The gap between the community and the government is brought closer through this strategy which had enabled NF to be recognized through the votes in this general election.

The number of $5,114,171$ or $49.73 \%$ female voters should be given due recognition as they fall under the deciding group, as to which party qualifies in this general election. Government programs especially those under the Ministry of Women and Family Development carried out various programs that enhanced the presence of this group in any field executed by them.

In fact, Puteri UMNO is a new group in the country's political arena and that has played a very important role in the success of NF in this general election. They are the most energetic catalyst in contributing to NF's success in the areas contested with the use of various strategies and approaching various levels of the community who were happy with their presence. Puteri UMNO was also successful in approaching the young generation voters and convinced them into voting for the betterment and prosperity of the nation. This is what the new generation wanted, who are more sensitive to economical issues, social stability and peace and also the candidates contesting as they will be the voters representative later in the state and central governments. The voter percentage increased greatly this time as it was the efforts of these groups in appealing to the people to cast their votes so as to ensure the future of the nation (Sivamurugan, 2004). The victory of NF was due to the strategies of this group in calling young voters especially 
during the last 48 hours before the commencement of the general election. This is the strength of NF who campaigned to ensure the continuity in leadership.

NF's victory was also due to the Islam Hadhari concept which is among Abdullah's main agenda and is being well received by the people as it is based on moderate Islamic teachings that have given due consideration to progressive development and tolerance. It does not raise any problems to the non-Muslim as discrimination does not exist in the said concept while it enhances the living standards of the society of this nation in its entirety. It practices good consideration among its people.

\section{Conclusion}

Generally, this election witnessed many shocking events and victories beyond expectations and a new shift in political culture of the country. It is also the people's support for Abdullah's political polices, which is a culture practiced all this while. Many voters who chose the opposition to show their dissatisfaction in the 1999 general election had now returned to NF. They do not share the ideologies of the opposition but are on-the-fence group which will generally vote NF. The other group is that of voters who are the new generation voters and are comfortable with the efforts by Abdullah as well as the female voters who have proven that their rights are guarded under the umbrella of NF administration. In five years, the opposition will strengthen their vehicle to face the challenge of this leadership. The scenario might be different with Anwar being freed on September 2, 2004, after a 6 year imprisonment. It depends on the role Anwar is going to play but at present, not much changes occurs because Anwar is still adjusting himself under the opposition platform which is ethnically divided too. Hence, the Malaysian political culture will remain based on the different practices and norms on the basis of pluralism capacity which have influenced NF's victory all this while.

\section{References}

Almond, Gabriel. (1983). "Communism And Political Culture Theory". Comparative Politics. Vol:15:2. New York: University of New York.

Verba, Sidney, Almond, Gabriel. (1972). The Civil Culture - Political Attitudes And Democracy In Five Nations. Princeton: Princeton University Press.

Husin Mutalib. (2000). "Malaysia's 1999 General Election: Signposts To Future Politics". Asian Journal Of Political Science. Vol:8:1. Singapore: Times Academic Press.

Ismail Kassim. (1979). Race, Politics and Moderation. Kuala Lumpur: Times Books International.

Kahn, Joel; Francis Loh Kok Wah. (1992). Fragmented Vision: Culture and Politics in Contemporary Malaysia. Australia: Allen \& Unwin.

Lim Kit Siang. (2001). BA Islamic State. Petaling Jaya: Democratic Action Party.

Massa: Special Edition On Post-Election. March 27 - April 2, 2004. Kuala Lumpur: Utusan Karya Sdn. Bhd.

Mauzy, Diane. (1983). Barisan Nasional: Coalition Government in Malaysia. Kuala Lumpur: Marican \& Sons Sdn. Bhd.

Means, Gordon. (1991). Malaysian Politics. London: Hodder \& Stoughton.

Milne, RS; Mauzy, Diane. (1978). Politics and Government in Malaysia. Canada: University of British Columbia Press.

Mohd Sayuti Omar. (2004). Pilihanraya Umum Ke 11: Suatu Tragedi. Kuala Lumpur: Tinta Merah.

Noordin Sopee. (2004). “Malaysia's Eleventh General Election: What Happened? So What?”. Paper presented at ISIS National Affairs Forum. March 23, 2004. Institute of Strategic and International Studies, Kuala Lumpur.

Pye, Lucian. (1985). Political Culture and Political Development. Princeton: Princeton University Press.

Rohani Ab. Ghani. (2004). "Penyertaan Masyarakat di Zon Timur dalam Pilihanraya 1999". Paper presented at Bengkel Pilihanraya Umum 1999 at EPF Social Security Training Institute, Bangi. February 19, 2004., organized by Universiti Utara Malaysia.

Rabuska, Alvin. (1973). Race and Politics in Urban Malaya. Stanford: Hoover Institution Press.

Sills, David. (1979). International Encyclopedia of Social Sciences. Vol:11:1, New York: The Free Press

Sivamurugan Pandian. (2004). Abdullah Ahmad Badawi: Jalan Ke Puncak. Kuala Lumpur: Utusan Publications.

Vasil, RK. (1980). Ethnic Politics in Malaysia. New Delhi: Radiant Publications.

\section{Notes}

Note 1. In the Kuala Berang Constituency by-election on August 28, 2004, NF retained the seat with a bigger majority. In the previous election, NF won with 1,695 votes but in the by-election, they managed to get 2,059 majority. NF also retained the Ba'Kelalan seat in Sarawak. 